\title{
Evaluasi manajemen pengadaan dan distribusi obat di dinas kesehatan kota Bandar Lampung periode tahun 2016
}

\author{
Nopiyansyah ${ }^{1 *}$, Anny Victor Purba ${ }^{2}$, Wahyudi Uun Hidayat ${ }^{3}$ \\ ${ }^{1}$ Ikatan Apoteker Indonesia Daerah Lampung. *Email: ryan_farm06@yahoo.co.id \\ 2,3Universitas Pancasila
}

\begin{abstract}
Evaluation of drug management on procurement and distribution at Bandar Lampung Health Authority
\end{abstract}

Background : Management of public medicine and medical supplies in aimstoen sure continuity, availability and affordability of efficient drug services, availability and affordability of efficient drug services. Procurementis a continuous activity starting from selection, determining the amount needed, adjusting between demand and budget, selecting procurement methods, selecting suppliers, determining contract specifications, monitoring procurement and payment processes.

Purpose : To determine the mechanism of drug procurement, drug distribution and delivery problems, constraints faced in the procurement and distribution of drugs.

Method: A qualitative descriptive with technique of collecting data through in-depth interviews and reviews of documents on drug procurement and distribution.

Results: Procurement of drug scarried out by the Pharmacy Installation of the Bandar Lampung Health Authority based on usage pattern was not in accordance with the report on the use of the drug request sheets that have been prepared by the Public health centers. There were 78 drug items $(44.3 \%)$ held more than those proposed, 77 drug items $(43.7 \%)$ drugs were heldless than proposed, and only 21 medicinal items $(12 \%)$ drugs that were carried out according to the ones proposed. Based on the results of the interview, problems with the distribution and delivery of drugs sent by the Pharmacy Installation founded problems which were 30 of Public health centers of drug has been sent expire date $<1$ year, 7 health centers have been sent expired date drugs and 26 health centers have been sent drugs that were not ordered. The most common constraints faced in the procurement and distribution of drugs carried out are not availabe drugs in pharmaceutical whole sales and drugs sent to the Public health centers not in accor dance with tho serequested by the Public health centers.

Conclusion : The procurement of drugs carried out and usage pattern is not in accordance with the report on the use of the drug request sheet that has been prepared successfully, ABC VEN method according to budget, the comordibity method was not appropriate wheres drugs most of which were held clinically not in accordance with the 10 most common diseases that occurred in the Bandar Lampung Health Authority in 2016.

\section{Keywords: Drugs management; Procurement; Distribution; Pharmacy installation}

Pendahuluan: Manajemen obat publik dan perbekalan kesehatan di bertujuan untuk menjamin kelangsungan, ketersediaan dan keterjangkauan pelayanan obat yang efisien, efektif dan rasional serta menjamin kualitas mutu obat. Pengadaan merupakan kegiatan yang berkesinambungan dimulai dari pemilihan, penentuan jumlah yang dibutuhkan, penyesuaian antara kebutuhan dan dana, pemilihan metode pengadaan, pemilihan pemasok, penentuan spesifikasi kontrak, pemantauan proses pengadaan dan pembayaran.

Tujuan: Untuk mengetahui mekanisme pengadaan obat, masalah pendistribusian dan pengiriman obat, kendala yang dihadapi dalam pengadaan dan pendistribusian obat.

Metode: Penelitian deskriptif kualitatif dengan pengumpulan data melalui wawancara mendalam dan telaah dokumen pengadaan dan pendistribusian obat.

Hasil: Pengadaan obat yang dilakukan Instalasi Farmasi Dinas Kesehatan Kota Bandar Lampung berdasarkan pola konsumsi tidak sesuai dengan laporan pemakaian lembar permintaan obat yang telah disusun puskesmas. Terdapat 
78 item obat $(44,3 \%)$ yang diadakan lebih dari yang diusulkan, 77 item obat $(43,7 \%)$ yang diadakan kurang dari yang diusulkan, dan hanya 21 item obat (12\%) yang diadakan sesuai dengan yang diusulkan. Berdasarkan hasil wawancara, masalah pendistribusian dan pengiriman obat yang dikirimkan oleh Instalasi Farmasi Dinas Kesehatan Kota Bandar Lampung yakni 30 puskesmas pernah dikirimkan obat expiredate $<1$ Tahun, 7 Puskesmas pernah dikirimkan obat yang sudah expiredate dan 26 puskesmas pernah dikirimkan obat yang tidak dipesan. Kendala yang paling sering dihadapi dalam pengadaan dan pendistribusian obat yang dilakukan oleh Instalasi Farmasi Dinas Kesehatan Kota Bandar Lampung yaitu obat kosong di pedagang besar farmasi dan obat yang dikirimkan ke puskesmas tidak sesuai dengan yang diminta oleh puskesmas.

Simpulan: Pengadaan obat yang dilakukan Instalasi Farmasi Dinas Kesehatan Kota Bandar Lampung berdasarkan pola konsumsi tidak sesuai dengan laporan pemakaian lembar permintaan obat yang telah disusun puksesmas, metode $A B C$ VEN sesuai anggaran, metode komordibitas belum sesuai dimana obat yang terbanyak diadakan secara klinis tidak sesuai dengan 10 penyakit terbanyak yang terjadi.

\section{Kata kunci: Manajemen obat; Pengadaan; Distribusi; Instalasi farmasi}

\section{PENDAHULUAN}

Rencana strategis kementerian Kesehatan tahun 2015-2019 meliputi peningkatan ketersediaan, keterjangkauan, pemerataan dan kualitas farmasi dan alat kesehatan. Tujuan pengelolaan obat publik yaitu untuk menjamin tersedianya obat bermutu dengan jenis dan jumlah yang tepat, tersebar secara merata dan teratur. Permasalahan pengelolaan obat publik saat ini yaitu tingkat ketersediaan obat ada yang kurang dan ada yang lebih sehingga ketersediaan tidak merata antar daerah, masih banyak item obat yang belum sesuai dengan kebutuhan pelayanan kesehatan dasar, terjadi kekosongan obat dan terdapat obat yang rusak/kadaluarsa (Quick, Hogerzeil, Rankin, Dukes, Laing, Garnett, \& O'Connor, 1997).

Banyak upaya dan program yang telah dilaksanakan secara berkesinambungan antara pemerintah dan masyarakat, baik program yang bernuansa promotif, preventif dan kuratif maupun yang bersifat rehabilitatif. Salah satunya adalah program pengelolaan obat di Provinsi, Kabupaten dan Kota. Kebijakan pemerintah terhadap peningkatan akses obat diselenggarakan melalui beberapa strata kebijakan yaitu Undang-Undang sampai Keputusan Menteri Kesehatan yang mengatur berbagai ketentuan berkaitan dengan obat.

Obat dan Perbekalan Kesehatan merupakan salah satu subsistem dari Sistem Kesehatan Nasional (SKN) tahun 2004 yang bertujuan agar tersedia obat dan perbekalan kesehatan yang aman, bermutu, bermanfaat serta terjangkau oleh masyarakat untuk menjamin terselenggaranya pembangunan kesehatan guna meningkatkan derajat kesehatan yang setinggi-tingginya. Obat merupakan komponen esensial dari suatu pelayanan kesehatan, selain itu karena obat sudah merupakan kebutuhan masyarakat, maka persepsi masyarakat tentang hasil dari pelayanan kesehatan adalah menerima obat setelah berkunjung ke sarana kesehatan, yaitu Puskesmas, Poliklinik, Rumah Sakit, Dokter praktek swasta dan lain-lain. Oleh karena vitalnya obat dalam pelayanan kesehatan, maka pengelolaan yang benar, efisien dan efektif sangat diperlukan oleh petugas di Pusat/Provinsi/ Kabupaten/Kota. Dengan demikian tanggung jawab pengadaan obat esensial untuk pelayanan kesehatan dasar bukan lagi menjadi tanggung jawab pemerintah pusat akan tetapi menjadi tanggung jawab pemerintah daerah Provinsi/Kabupaten/Kota. Melihat data tersebut, maka pemerintah khususnya pemerintah daerah Provinsi/Kabupaten/Kota akan merasakan beban yang sangat besar terhadap APBD/DAU setiap tahunnya.

Instalasi Farmasi Kota (IFK) merupakan suatu organisasi Unit Pelaksana Teknis (UPT) Dinas Kesehatan Kota Bandar Lampung yang wilayah meliputi 30 puskesmas. Distribusi obatnya dilaksanakan setiap triwulan dengan menggunakan pull distribution system dengan cara puskesmas melakukan permintaan obat berdasarkan jumlah kebutuhan obat masing-masing Puskesmas yang diajukan oleh Kepala Puskesmas kepada Kepala Dinas Kesehatan Kota Bandar Lampung dengan menggunakan format Laporan Pemakaian Lembar Permintaan Obat (LPLPO), sedangkan permintaan

Nopiyansyah"* Ikatan Apoteker Indonesia Daerah Lampung. *Email :ryan_farm06@yahoo.co.id

Anny Victor Purba ${ }^{2}$, Wahyudi Uun Hidayat ${ }^{3}$ Universitas Pancasila 
dari puskesmas pembantu kepada puskesmas dilakukan secara periodik menggunakan Laporan Pemakaian Lembar Permintaan Obat (LPLPO) sub unit (Keputusan Presiden Republik Indonesia, 2009). Untuk menjamin ketersediaan obat di pelayanan kesehatan dan juga menjaga citra pelayanan kesehatan itu sendiri, maka sangatlah penting menjamin ketersediaan dana yang cukup untuk pengadaan obat esensial, namun lebih penting lagi dalam mengelola dana penyediaan obat secara efektif dan efisien (Kementerian Kesehatan Republik Indonesia, 2010).

Pada survei pendahuluan, ada beberapa masalah ditemukan yang terkait dengan manajemen pengadaan dan distribusi obat yaitu : pengadaan dan distribusi obat di Instalasi Farmasi Kota dan Puskesmas belum menggunakan suatu analisis, hanya berdasarkan perkiraan konsumsi. Kurangnya perencanaan menyebabkan terjadinya kekosongan obat atau stock out. Frekuensi pengadaan tidak terencana sehingga biaya yang harus dikeluarkan untuk pemesanan tidak dapat diprediksi.

Pada penelitian sebelumnya karena banyaknya obat yang tidak tersedia, sehingga mendorong pasien yang tidak dapat terlayani dan harus mencari apotek lain (Boku, Satibi, \& Yasin, 2019). Hal tersebut sesuai dengan penelitian sebelumnya menunjukkan bahwa lemahnya sistem pendukung yang berperan dalam proses pengelolaan, penyimpanan dan distribusi obat di Kabupaten Lampung Selatan menyebabkan proses pengelolaan, penyimpanan dan distribusi obat tidak efektif dengan dibuktikan tidak tercapainya indikatorindikator pengadaan, penyimpanan dan distribusi obat. Penelitian terkait dengan pengelolaan obat dengan perencanaan, pengadaan dan penyimpanan obat belum sesuai dengan pedoman pengelolaan obat yang ada dan menunjukan bahwa pengelolaan obat belum baik karena belum sesuai dengan standar yang ditetapkan Departemen Kesehatan Republik Indonesia (Nurniati, Lestari, \& Lisnawaty, 2017; Syukriati, 2016; Danu, 2013).

Evaluasi ini digunakan untuk mengetahui kelemahan dan kesulitan dalam pengadaan dan distribusi obat sebagai masukan untuk melakukan perbaikan pengadaan dan distribusi obat di Dinas Kesehatan Kota Bandar Lampung. Rumusan masalah dalam penelitian ini adalah: bagaimana mekanisme pengadaan obat, ketersediaan anggaran terhadap proses pengadaan obat, ketersediaan anggaran terhadap proses pendistribusian obat, mekanisme alur distribusi obat, kendala dalam proses perencanaan pengadaan obat dan kendala dalam proses distribusi obat.

\section{METODE PENELITIAN}

Penelitian deskriptif kualitatif, dengan fokus penelitian yakni Dinas Kesehatan Kota Bandar Lampung. Data yang dikumpulkan berupa data kuantitatif dan data kualitatif. Data kuantitatif diambil dari observasi dokumen-dokumen terkait persediaan obat yang ada di Instalasi Farmasi Kota (IFK) dan beberapa puskesmas Kota Bandar Lampung meliputi APBD, Askes, Maskin dan dokumen lain yang dapat mendukung data penelitian.

Data kualitatif diperoleh dari wawancara mendalam dengan kepala IFK, Bagian logistik, Bagian anggaran dan bagian yang terkait dengan pengadaan. Penelitian ini dilaksanakan pada bulan Maret 2017 sampai dengan Juli 2018. dengan populasi semua pegawai di IFK dan yang menjadi responden pada penelitian ini adalah : Kepala IFK, bagian logistik dan bagian anggaran. Responden yang dipilih sesuai dengan prinsip-prinsip yang berlaku seperti berdasarkan pengetahuan yang dimiliki yang berkaitan dengan topik penelitian dan kecukupan informasi yang diperoleh dari responden harus dapat menggambarkan seluruh fenomena yang berkaitan dengan topik penelitian. Untuk penelitian kuantitatif dengan populasi semua obat di IFK dan sampelnya adalah data obat-obatan yang termasuk dalah kelompok $A, B$ dan $C$.

Analisa data dilakukan terhadap masing-masing variabel berdasarkan data yang telah dikumpulkan. Analisis dilakukan dengan mendeskripsikan perekaman data hasil wawancara mendalam, hasil observasi dan perhitungan data kuantitatif, kemudian mengtriangulasikan ketiga instrumen tersebut. Penyajikan data yang diolah tersebut dalam bentuk narasi, kuotasi dan tabulasi untuk memberi gambaran yang yang jelas tentang topik yang disajikan. Selanjutnya, mengkaitkan interpretasi dari peneliti sendiri dan menghubungkannya dengan teori atau hasil penelitian orang lain yang bisa mendukung (Dye, 2001).

Setelah semua data terkumpul, yakni hasil survei dokumen observasi pengadaan dan wawancara

Nopiyansyah"* Ikatan Apoteker Indonesia Daerah Lampung. *Email :ryan_farm06@yahoo.co.id

Anny Victor Purba ${ }^{2}$, Wahyudi Uun Hidayat ${ }^{3}$ Universitas Pancasila 
Evaluasi manajemen pengadaan dan distribusi obat di dinas kesehatan kota Bandar Lampung periode tahun 2016

mendalam. Selanjutnya dilakukan analisis dengan; mendeskripsikan semua hasil survei dokumen observasi dan wawancara mendalam, menyusun transkrip hasil pengumpulan data, coding, yaitu proses memecahkan data menjadi unit-unit berupa kata, kalimat, paragraf pendek, maupun bagian data yang memiliki makna tersendiri, axial coding, yaitu proses memahami unit-unit tersebut, merangkum kembali unit-unit dalam bentuk kategori dan hubungan antar kategori, dan menginterpretasikan semua hasil tersebut untuk diambil kesimpulan.

\section{HASIL}

\section{Pengadaan Obat}

Manajemen Pengadaan barang/jasa yang baik harus dilakukan secara elektronik atau eprocurement dapat dilakukan dengan E-Tendering atau E-Purchasing. Pengadaan obat dilaksanakan oleh kelompok kerja unit layanan pengadaan atau pejabat pengadaansatuan kerja berdasarkan perintah dari pejabat pembuat komitmen (PPK) satuan kerja dibidang kesehatan (Nurniati, Lestari,\& Lisnawaty, 2017).

Pengadaan obat dengan prosedur $E$ Purchasing; Satuan kerja dibidang kesehatan menyampaikan rencana kebutuhan obat kepada PPK, PPK melihat katalok obat dalam portal pengadaan yang memuat nama obat, nama penyedia, kemasan, harga, satuan terkecil, distributor dan kontrak payung penyedia obat, PPK menetapkan daftar pengadaan obat sesuai kebutuhan dan ketersediaan anggaran yang terdiri atas: Daftar pengadaan obat berdasarkan katalog elektronik (E-katalog) obat, yaitu daftar kebutuhan obat yang tercantum dalam sistem Katalog Elektronik (E-katalog) obat yang ditayangkan di portal pengadilan nasional. Daftar Pengadaan obat diluar katalog elektronik (E-katalog) obat sebagaimana dalam formulir daftar kebutuhan obat yang tidak terdapat dalam katalog elektronik (Ekatalog) obat. Kedua daftar pengadaan obat tersebut harus ditandatangani oleh PPK. Daftar pengadaan Obat berdasarkan katalog elektronik (Ekatalog) obat sebagaimana contoh dalam formulir yang sudah ditandatangani selanjutnya diteruskan oleh PPK kepada Pokja ULP/Pejabat Pengadaan untuk diadakan dengan metode E- Purchasing. Daftar Pengadaan Obat diluar Katalog Elektronik obat selanjutnya diteruskan oleh PPK kepada Pokja
ULP/Pejabat Pengadaan untuk diadakan dengan metode lainnya. Pembelian obat secara elektronik (E-Purchasing) berdasarkan sistem Katalog Elektronik (E-Catalogue) obat dilaksanakan oleh PPK dan Pokja ULP atau pejabat Pengadaan melalui aplikasi E-Purchasing pada website layanan pengadaan secara elektronik (LPSE), sesuai peraturan kepala lembaga kebijakan pengadaan barang/jasa pemerintah nomor 17 tahun 2012 tentang E-Purchasing.

Untuk dapat menggunakan aplikasi EPurchasing, PPK dan pokja ULP atau pejabat pengadaan harus memiliki kode akses (user ID dan password) dengan cara melakukan pendaftaran sebagai pengguna kepada LPSE setempat. Tahapan yang dilakukan dalam pengadaan obat melalui E Purchasing adalah sebagai berikut (27); Pokja ULP/Pejabat pengadaan membuat paket pembelian obat dalam aplikasi E-Purchasing berdasarkan daftar pengadaan obat yang diberikan oleh PPK. Paket pembelian obat dikelompokkan berdasarkan penyedia, Pokja ULP/pejabat pengadaan selanjutnya mengirimkan permintaan pembelian obat kepada penyedia obat/industri farmasi yang termasuk dalam kelompok paket pengadaan, Penyedia obat/Industri farmasi yang telah menerima permintaan pembelian obat melalui E-Purchasing dari Pokja ULP/ pejabat pengadaan memberikan persetujuan atas permintaan pembelian obat dan menunjuk distributor/PBF. Apabila menyetujui, penyedia obat/industri farmasi menyampaikan permintaan pembelian kepada distributor /PBF untuk ditindak lanjuti. Apabila menolak, penyedia obat /industri farmasi harus menyampaikan alasan penolakan, persetujuan penyedia obat/industri farmasi kemudian diteruskan oleh Poka ULP/Pejabat pengadaan kepada PPK untuk ditidak lanjuti. Dalam hal permintaan pembelian obat mengalami penolakan dari penyedia obat/industri farmasi, maka ULP melakukan metode pengadaan lainnya. PPK selanjutnya melakukan perjanjian/kontrak jual beli terhadap obat yang telah disetujui dengan distributor/PBF yang ditunjuk oleh penyedia obat/Industri Farmasi. Distributor/PBF kemudian melaksanakan penyediaan obat sesuai dengan isi perjanjian / kontrak jual beli. PPK selanjutnya mengirm perjanjian pembelian obat serta melengkapi riwayat pembayaran dengan cara mengunggah (upload) pada aplikasi E-Purchasing.

Nopiyansyah"* Ikatan Apoteker Indonesia Daerah Lampung. *Email :ryan_farm06@yahoo.co.id

Anny Victor Purba ${ }^{2}$, Wahyudi Uun Hidayat ${ }^{3}$ Universitas Pancasila 
PPK melaporkan ítem dan jumlah obat yang ditolak atau tidak dipenuhi oleh penyedia obatindustri farmasi kepada kepala lembaga kebijakan pengadaan barang/jasa pemerintah (LKPP) C.q Direktur pengembangan sistem katalog, tembusan kepada direktur jenderal bina kefarmasian dan alat kesehatan c.q direktur bina obat publik dan perbekalan kesehatan paling lambat 5 (lima) hari kerja.

\section{Distribusi Obat}

Kegiatan distribusi obat di IFK diamati dengan menggunakan instrumen daftar tilik stratifikasi pengelolaan obat publik dan perbekalan kesehatan Kota (Departemen Kesehatan Republik Indonesia, 2007). Proses pengadaan obat dilakukan dengan sistem E-Catalogue secara elektronik. Sistem ini diatur dalam Peraturan Menteri Kesehatan tentang Petunjuk Pelaksanaan Pengadaan Obat Dengan Prosedur E-Purchasing Berdasarkan E-Catalogue (Kementerian Kesehatan Republik Indonesia, 2013).

Penerapan sistem ini bertujuan untuk meningkatkan transparansi dalam proses pengadaan obat, meningkatkan persaingan yang sehat dalam penyediaan layanan publik dan penyelenggaraan pemerintahan yang baik, serta meningkatkan efektifitas dan efisiensi dalam managemen proses pengadaan obat (Departemen Kesehatan Republik Indonesia, 2008).

Dari hasil wawancara di lapangan maka diperoleh beberapa jawaban mulai dari Kepala Unit Pelayanan Terpadu (UPT) Instalasi Farmasi, menyebutkan bahwa tidak mengadakan obat, IFK hanya menyimpan dan distribusi, adapun pengadaan obat dilakukan oleh Dinas Kesehatan Kota Bandar Lampung dan pengadaannya melalui e-katalog, penyelenggaraan diselenggarakan hanya 1 kali dalam setahun dan sesuai formularium nasional (FORNAS).

Berdasarkan jawaban dari Kabid Sumber Daya Kesehatan (SDK) bahwa mekanisme pengadaan obat di Instalasi Farmasi berdasarkan rencana kebutuhan obat (RKO) seluruh puskesmas di Kota Bandar Lampung, mekanisme pengadaannya dengan cara e-purchasing, pengadaan sudah dilakukan dengan e-katalog. Sedangkan kalau tidak menggunakan e-katalog maka dilakukan secara konvensional dengan 1 kali sebulan. Frekuensi pengadaan obat dilakukan dalam satu tahun (2016) Anggaran adalah 1 kali setahun, obat yang diadakan seluruhnya ada di FORNAS karena Puskesmas sudah punya formularium sendiri yang merujuk ke Formularium Nasional (FORNAS). Untuk obat-obat yang tidak ada dalam FORNAS maka pengadaan obatnya dilakukan dengan cara pembelian langsung.

Jawaban dari Kasie Kefarmasian bahwa mekanisme pengadaan obat di Instalasi Farmasi yaitu pengadaan sudah dilakukan dengan e-katalog. Sedangkan kalau tidak menggunakan e-katalog maka dilakukan pengadaan pembelian secara langsung sesuai dengan kebutuhan puskesmas. Frekuensi pengadaan dalam satu tahun (2016) Anggaran adalah E-Purchasing sebanyak 1 kali setahun. Obat yang diadakan seluruhnya ada di FORNAS untuk Dinkes Kota Bandar Lampung sudah mempunyai formularium sendiri yang diadopsi dari FORNAS, sedangkan cara pengadaan obat yang tidak temasuk di FORNAS yaitu pembelian langsung.

Mekanisme penyusunan Laporan Pemakaian Lembar Permintaan Obat (LPLPO) di Puskesmas stok awal obat ditambah stok awal masuk stok obat dibulan tersebut, pengeluaran obat tersebut, pengeluaran obat pasti, pengeluaran obat di induk puskesmas dan hasil akhir jumlah obat tersebut menjadi stok akhir obat pada bulan tersebut. Selain itu dilakukan dengan laporan rekap harian laporan dihitung dari awal penerimaan lalu dikurangi pengeluaran yang diambil 1 bulan. LPLPO disusun berdasarkan jumlah penerimaan distribusi dari Instalasi Farmasi Kota (IFK) dan jumlah pemakaiaan di puskesmas. Laporan pemakaiaan puskesmas pembantu, poskeskel, puskesmas induk direkap 1 bulan lalu dilakukan penghitungan stok awal ditambah penerimaan lalu dikurangi pengeluaran yang direkap 1 bulan. Pemakaiaan harian dari pustu, poskeskel, poli-poli, UGD, rawat inap, VK, posyandu, direkap setiap bulan pemakaiannya, dihitung sisa stok akhirnya. LPLPO disusun bersama pada saat rapat penyusunan rencana kebutuhan obat stok akhir-stok awal, bulan berikutnya menjadi stok awal persediaan awal penempatan stok akhir atau berdasarkan sisa stok gudang Puskesmas dan poskel.

Nopiyansyah"* Ikatan Apoteker Indonesia Daerah Lampung. *Email :ryan_farm06@yahoo.co.id

Anny Victor Purba ${ }^{2}$, Wahyudi Uun Hidayat ${ }^{3}$ Universitas Pancasila 
Evaluasi manajemen pengadaan dan distribusi obat di dinas kesehatan kota Bandar Lampung periode tahun 2016

Hal yang mendasari penyusunan LPLPO tahunan adalah pengeluaran dan penerimaan obat skema 1 tahun, LPLPO bulanan, stok awal, pemakaian harian, usulan permintaan obat dari pemakaian obat dan sisa stok. Adapun yang menyebutkan bahwa hal yang mendasari penyusunan LPLPO tahunan adalah metode konsumtif berdasarkan kata-kata pemakaian obat.

Tabel 1. Distribusi Frekuensi Responden

\begin{tabular}{lcc}
\hline Responden & Frekwensi (f) & \multicolumn{1}{c}{ Jabatan } \\
\hline Dinas Kesehatan & 3 Orang & $\begin{array}{l}\text { Kabid, Kasie dan Ka.UPT IF } \\
\text { Kota Bandar Lampung }\end{array}$ \\
$\begin{array}{l}\text { Puskesmas } \\
\text { Total }\end{array}$ & $\begin{array}{c}\text { 30 Orang } \\
\text { 33 Responden }\end{array}$ & Pengelola Obat Puskesmas \\
\hline
\end{tabular}

Mekanisme penyusunan Laporan Pemakaian Lembar Permintaan Obat (LPLPO) di Puskesmas stok awal obat ditambah stok awal masuk stok obat dibulan tersebut, pengeluaran obat tersebut, pengeluaran obat pasti, pengeluaran obat di induk puskesmas dan hasil akhir jumlah obat tersebut menjadi stok akhir obat pada bulan tersebut. Hal yang mendasari penyusunan LPLPO tahunan adalah pengeluaran dan penerimaan obat skema 1 tahun, LPLPO bulanan, stok awal, pemakaian harian, usulan permintaan obat dari pemakaian obat dan sisa stok.

Tabel 2.Profil Item Obat Yang Diadakan Dinas Kesehatan Kota Bandar Lampung

\begin{tabular}{lcc}
\hline \multicolumn{1}{c}{ Katagori } & Jumlah & Persentase \\
& & $82 \%$ \\
\hline Jumlah Obat yang diadakan & 175 & $96 \%$ \\
Generik Sesuai Fornas & 166 & $3 \%$ \\
Branded Sesuai Fornas & 6 & $1 \%$ \\
Tidak Sesuai Fornas & 3 & $18 \%$ \\
Jumlah Alkes yang diadakan & 28 & $\mathbf{1 0 0 \%}$ \\
Total Obat dan Alkes yang diadakan & $\mathbf{2 0 3}$ & \\
\hline
\end{tabular}

\section{Keterangan:}

N obat $=175$ obat dan alkes $=203$

Dari data diatas diketahui jumlah obat yang diadakan ke PPK sebanyak 175 item obat dimana 166 obat merupakan obat generik dan 6 obat branded.166 item obat yang diadakan terdapat 3 obat yang tidak sesuai dengan Formularium Nasional, yakni siobion, coparsetin, ambroxol. 
Evaluasi manajemen pengadaan dan distribusi obat di dinas kesehatan kota Bandar Lampung periode tahun 2016

Tabel 3. Daftar Obat Yang Melebihi Dari Jumlah Yang Diusulkan Dengan Obat Yang Diadakan.

\begin{tabular}{llc}
\hline No & Daftar Obat & Jumlah Selisih pengadaan dengan usulan \\
& & \\
\hline 1 & Klorfeniramin maleat (CTM) tablet 4 mg & $1,807,930$ \\
2 & Prednison tablet 5 mg & $1,243,175$ \\
3 & Piridoksin hcl tablet & $1,022,927$ \\
4 & Tiamin tab (vit B1) & 394,540 \\
5 & Zinc tab & 174,600 \\
6 & Natrium Bikarbonat tablet 500 mg & 170,652 \\
7 & Ciprofloxacin Tab 500 mg & 158,450 \\
8 & Klorokuin fosfat tablet 250 mg & 134,200 \\
9 & Masker & 86,249 \\
10 & Amlodipin 5 mg & 66,180 \\
11 & Deksametason tablet 0,5 mg & 66,000 \\
12 & Allopurinol tablet 100 mg & 59,900 \\
13 & Mineral Mix & 58,414 \\
14 & Asam askorbat (vit c) tablet 50 mg & 55,800 \\
15 & Nifedifine Tab /Farmalat & 53,545 \\
16 & Obat Flu + batuk ( Coparsetin ) & 53,050 \\
17 & Simvastatin tab & 49,825 \\
18 & INH 100 mg & 49,200 \\
19 & Asam mefenamat 500 mg & 47,800 \\
20 & Omeprazol 20 mg kaps & 30,020 \\
21 & ACT ( Artesunete \& Amodiaquin ) & 21,114 \\
22 & Alat Suntik sekali pakai 1 ml & 20,898 \\
23 & Metoklorpropamide tab & 20,800 \\
24 & I.V.Cateter (abbocath) 22 & 14,506 \\
25 & Albendazol 400 mg & 13,575 \\
26 & I.V.Cateter (abbocath) 24 & 12,680 \\
27 & Metronidazol tablet 250 mg & 10,800 \\
\hline
\end{tabular}

Tabel 3.gambaran 27 jumlah obat terbanyak yang selisihnya melebihi 10.000 dari total jumlah pengusulan LPLPO dibandingkan dengan jumlah obat yang diadakan.

\section{Gambar 1. Kesesuain Obat Yang Diusulkan Dengan Obat Yang Diadakan Dengan Rincian Sebagai Berikut}

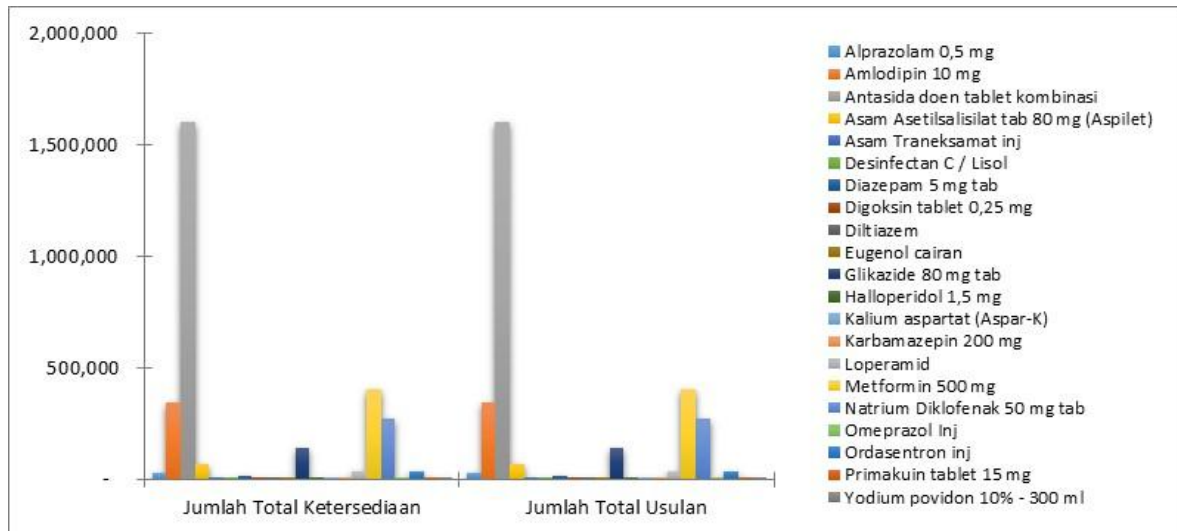

Nopiyansyah"* Ikatan Apoteker Indonesia Daerah Lampung. *Email :ryan_farm06@yahoo.co.id Anny Victor Purba ${ }^{2}$, Wahyudi Uun Hidayat ${ }^{3}$ Universitas Pancasila 
Berdasarkan grafik di atas, tampak bahwa obatobat yang memiliki jumlah sama antara ketersediaan dengan usulan adalah Alprazolam 0,5 mg, Amlodipin $10 \mathrm{mg}$. Antasida doen tablet kombinasi, Asam Asetilsalisilat tab $80 \mathrm{mg}$ (Aspilet), Asam Traneksamat inj, Desinfectan C / Lisol, Diazepam 5 $\mathrm{mg}$ tab, Digoksin tablet 0,25 mg, Diltiazem, Eugenol cairan, Glikazide $80 \mathrm{mg}$ tab, Halloperidol $1,5 \mathrm{mg}$, Kalium aspartat (Aspar-K), Karbamazepin 200 mg, Loperamid, Metformin $500 \mathrm{mg}$, Natrium Diklofenak $50 \mathrm{mg}$ tab, Omeprazol Inj, Ordasentron inj, Primakuin tablet $15 \mathrm{mg}$ dan Yodium povidon $10 \%$ $300 \mathrm{ml}$.

Obat-obat yang memiliki selisih tertinggi antara jumlah ketersediaan dibandingkan dengan usulan (ketersediaan lebih rendah dibandingkan dengan usulan) tiga terbesar secara berturut-turut yakni adalah Parasetamol tablet $500 \mathrm{mg}$ dengan selisih kekurangan 1.136.300, kemudian Amoksisilin 500 mg dengan selisih kekurangan 949.870 dan Gliseril guayakolat tablet 100 mgdengan selisih kekurangan 664.400. Hal ini mengindikasikan bahwa obat-obat tersebut masih kekurangan di fasilitas kesehatan. Gambaran jumlah obat yang diadakan melebihi jumlah obat yang diusulkankan pada LPLPO dari puskesmas, terdapat 30 item obat yang pengadaanya terdapat selisih diatas 10.000 jumlah obat yang diadakan dengan yang di pesan.

Data yang diperoleh menunjukan bahwa obat paling terbanyak semuanya merupakan obat generik, hal ini telah sesuai dengan arahan pemerintah melalui Kementerian kesehatan untuk mengutamakan penggunaan obat generik, dari 9 item obat terbanyak total jumlah obat yakni $14,498,500$ dengan menghabiskan anggaran sebanyak Rp.1.954.226.200,00.

Pengumpulan data sekunder di dapatkan jumlah penyakit terbanyak tahun 2016 dihubungkan dengan 9 obat terbanyak yang diadakan tahun 2016, secara klinis 9 obat terbanyak yang diadakan oleh Dinas Kesehatan Kota Bandar Lampung seperti belum sesuai dengan pola penyakit sehingga untuk obat yang digunakan dalam pengobatan 10 penyakit terbanyak masih belum tersedia secara baik.

Berdasarkan hasil wawancara dengan Kepala UPT Instalasi Farmasi bahwa anggaran pengadaan dan pendistribusian selalu tersedia, sumber anggaran yang dimiliki untuk pengadaan obat berasal dari APBN, ketersediaan anggaran tidak mempengaruhi waktu pengadaan obat karena setiap tahun anggaran perencanaan obat sudah diperhitungkan untuk waktu rentang obat (18 bulan). Ketersediaan obat tidak mempengaruhi waktu pendistribusian obat karena persediaan obat untuk 18 bulan, 1 tahun berjalan dan 6 bulan tahun berikutnya.

\section{PEMBAHASAN}

Distribusi adalah suatu rangkaian kegiatan dalam rangka pengeluaran dan pengiriman obat, terjamin keabsahan, tepat jenis dan jumlah secara merata dan teratur untuk memenuhi kebutuhan unit-unit pelayanan kesehatan (Asli, 2007). Instalasi Farmasi Kota Bandar Lampung melayani permintaan distribusi obat untuk 30 puskesmas yang tersebar diseluruh wilayah kerja Dinas Kesehatan Kota Bandar Lampung. Alokasi biaya distribusi dapat dipergunakan secara efektif dan efisien, maka IFK perlu membuat peta lokasi dari unit-unit pelayanan kesehatan di wilayah kerjanya. Jarak $(\mathrm{km})$ dan waktu tempuh (jam) antara IFK dengan setiap unit pelayanan kesehatan dicantumkan pada peta lokasi serta sarana distribusi yang digunakan (Departemen Kesehatan Republik Indonesia, 2007).

Sistem distribusi yang digunakan adalah pull distibution system, dimana puskesmas melakukan permintaan obat ke IFK sesuai dengan kebutuhan obat puskesmas. Apabila puskesmas mengalami kekosongan obat atau kejadian KLB maka sewaktuwaktu dapat melakukan permintaan obat. Distribusi obat rutin dilaksanakan per-triwulan berdasarkan jadwal distribusi obat yang telah di tetapkan oleh IFK. Hasil penelitian Herman dan Handayani, menyatakan bahwa proses distribusi obat ke puskesmas dilakukan tiap bulan berdasarkan permintaan puskesmas. Hanya ada satu kota yang permintaannya dilakukan tiap triwulan (Herman, 2009).

Tata cara distribusi obat ke Unit Pelayanan Kesehatan dapat dilakukan cara penyerahan oleh IFK ke Unit Pelayanan Kesehatan (UPK), pengambilan sendiri oleh UPK di IFK, atau cara lain yang ditetapkan oleh Dinas Kesehatan Kabupaten/Kota (Kementerian Kesehatan Republik Indonesia, 2010). Hal ini sesuai dengan yang terjadi di IFK Kota Bandar Lampung, dimana tata cara

Nopiyansyah"* Ikatan Apoteker Indonesia Daerah Lampung. *Email :ryan_farm06@yahoo.co.id

Anny Victor Purba ${ }^{2}$, Wahyudi Uun Hidayat ${ }^{3}$ Universitas Pancasila 
distribusi obat dari IFK ke puskesmas dengan cara petugas puskesmas mengambil sendiri obat tersebut sesuai jadwal distribusi rutin. Apabila terjadi kekurangan obat di suatu puskesmas, IFK dapat memenuhi permintaan kekosongan obat tersebut kepada puskesmas yang bersangkutan melalui surat permintaan pendistribusian obat yang ditandatangani oleh kepala pukesmas.

Pencapaian keberhasilan ketepatan waktu distribusi obat masih rendah yaitu di bawah $60 \%$, hanya satu puskesamas dengan ketepatan distribusi $80 \%$.Hal ini karena distribusi obat banyak diluar jadwal distribusi rutin.Distribusi obat diluar jadwal rutin ini disebabkan karena adanya permintaan obat dari puskesmas akibat kekosongan obat, KLB dan distribusi khusus dari IFK.

Salah satu upaya untuk menjamin kecukupan obat di kabupaten/Kota adalah dengan memperbaiki mutu manajemen obat di IFK dan memperbaiki penggunaan obat di puskesmas. Mutu manajemen obat dapat ditingkatkan melalui intervensi komprehensif mulai perencanaan, pengadaan, inventory, pendistribusian dan pencatatan dan pelaporan penggunaan obat oleh Kabupaten/Kota serta pemantauan kecukupan obat dari waktu ke waktu (Dwiprahasto, 2004).

Persentase penyimpangan jumlah obat yang didistribusikan adalah persentase dari selisih antara jumlah obat yang seharusnya didistribusikan dengan kenyataan pemberian obat. Penyimpangan pendistribusian obat terjadi apabila jumlah permintaan obat dari puskesmas tidak sesuai dengan jumlah pemberian obat dari IFK. Penyimpangan ini terjadi disebabkan oleh beberapa faktor. Apabila ada jenis obat tertentu yang diminta dari puskesmas tetapi tidak diberi oleh IFK karena memang untuk jenis obat tersebut tidak ada stoknya (kosong). Untuk jumlah kuantum obat dengan jumlah pemberian lebih banyak daripada permintaan, dikarenakan adanya penumpukan stok obat jenis tertentu sperti obat program di IFK. Penumpukan obat-obatan tertentu (obat program) terjadi karena adanya dropping obat dari Pusat atau Provinsi diluar permintaan obat dari Dinas Kesehatan Kota Bandar Lampung (Departemen Kesehatan Republik Indonesia, 2010).

Kemungkinan permintaan obat dari puskesmas tidak sesuai dengan jumlah pemberian obat dari IFK, pendistribusian obat perlu adanya kesesuaian antara jumlah obat yang dibutuhkan oleh unit pelayanan dengan jumlah obat yang tersedia di gudang farmasi (Ukai, 2009).

Persentase rata-rata waktu kekosongan obat adalah persentase jumlah hari kekosongan obat dalam waktu satu tahun. Berdasarkan hasil penelitian, pada tahun 2011 persentase rata-rata waktu kekosongan obat indikator di IFK $(33,1 \%)$ dan puskesmas (14,4\% -35,7\%) (Murwati, 2011).

Kekosongan obat terutama obat yang bersifat live saving dapat mengakibatkan kematian dan kekosongan obat ini akan sangat mempengaruhi pola pengobatan yang dilakukan di unit pelayanan kesehatan. Kekosongan obat di puskesmasakan menganggu kualitas pelayanan kefarmasian sebagai salah satu faktor yang menopang pelayanan kesehatan paripurna. Hal ini akan berdampak pada tujuan akan pemenuhan kebutuhan obat yang bermutu, lengkap, dalam jumlah yang cukup, terjamin khasiatnya, aman, efektif, efisien dan berkesinambungan tidak akan tercapai (Kristin, 2007). Pendistribusian obat dalam satu bulan dilakukan dengan 2 sistem pengiriman yaitu distribusi triwulan (tiap 3 bulan)/3 kali dalam satu tahun (triwulan) dan distribusi obat program/antar waktu (tiap bulan). Pengiriman obat rutin dilakukan setelah formulir LPLPO dikirimkan ke Dinas Kesehatan. Frekuensi pengiriman obat rutin dilakukan 4 kali dalam setahun yaitu setiap 3 bulan sekali sedangkan LPLPO setiap 1 bulan sekali dikirim ke IFK dengan demikian, pengiriman obat rutin tetap dilakukan setiap 3 bulan sekali walaupun LPLPO dikirim setiap bulan. Hasil wawancara dengan responden menyebutkan bahwa lama waktu tunggu obat setelah dipesan yaitu selama satu bulan atau dalam setahun. Responden dari puskesmas yang menyebutkan bahwa obat rutin setiap 3 bulan, obat triwulan waktu tunggu 1 bulan, adapun jadwal pergantian antar waktu (PAW) senin dan rabu, LPLPO sebulan sebelum pendistribusian, PAW sehari sebelum permintaan atau 3 minggu. Masalah pendistribusian obat dari Dinas Kesehatan yang terjadi di puskesmas karena item obat yang telah dipesan merupakan item obat program datang dari pusat dan ada moment-moment nasional. Alasan lain karena masalah yang terjadi terkait pengiriman obat dari Dinas Kesehatan ke puskesmas karena berdasarkan FIFO/FEFO, karena salah mengirim barang yang seharusnya punya puskesmas lain,

Nopiyansyah"* Ikatan Apoteker Indonesia Daerah Lampung. *Email :ryan_farm06@yahoo.co.id

Anny Victor Purba ${ }^{2}$, Wahyudi Uun Hidayat ${ }^{3}$ Universitas Pancasila 
Evaluasi manajemen pengadaan dan distribusi obat di dinas kesehatan kota Bandar Lampung periode tahun 2016

karena obat yang ED masih lama belum ada sehingga obat yang ED harus segera dihabiskan, obat yang diterima dari gudang dinas kesehatan dengan kondisi ED seperti itu, obat-obatan yang di drop dari pusat, biasanya obat-obatan yang penyimpanan di IFK tidak mengetahui kalau stok ED yang dekat, penyimpanan di IFK tidak FEFO dan dikarenakan banyaknya item obat permintaan terbatas tenaga gudang.

Kendala-kendala yang dihadapi dalam proses pengadaan obat adalah obat yang tersedia di pabrik tersebut kadang kosong atau tidak tersedianya item obat yang dibutuhkan pada distributor/ pabrik. Kendala ini merupakan kendala yang paling umum teradi hampir di semua wilayah di Indonesia.

Kendala-kendala yang dialami dalam pengiriman obat setelah formulir LPLPO dikirimkan ke Dinas Kesehatan adalah kebutuhan obat tidak semua terpenuhi atau tidak tersedia obat yang diminta dan kekosongan obat. Kendala ini dapat terlihat dengan ketidak sesuaiannya data permintaan obat-obat oleh puskesmas melalui LPLPO dengan jumlah obat yang diadakan dan yang didistribusikan ke puskesmas-puskesmas di Kota Bandar Lampung

\section{SIMPULAN}

Berdasarkan analisa data yang telah dilakukan, didapatkan beberapa kesimpulan penelitian sebagai berikut : Pengadaan obat yang dilakukan Instalasi Farmasi Dinas Kesehatan Kota Bandar Lampung berdasarkan pola konsumsi tidak sesuai dengan LPLPO yang telah disusun puksesmas, terdapat 78 item obat $(44,3 \%)$ yang diadakan lebih dari yang diusulkan, 77 item obat $(43,7 \%)$ obat diadakan kurang dari yang disusulkan dan hanya 21 item obat $(12 \%)$ obat yang diadakan sesuai dengan yang diusulkan. Pengadaan obat yang dilakukan Instalasi Farmasi Dinas Kesehatan Kota Bandar Lampung berdasarkan metode komordibitas belum sesuai dimana obat yang terbanyak diadakan secara klinis terhadap 10 penyakit terbanyak yang terjadi di Kota Bandar lampung tahun 2016.

Pendistribusian dan pengriman obat yang dikirimkan oleh Instalasi Farmasi Dinas Kesehatan Kota Bandar Lampung berdasarkan hasil wawancara ditemukan malasah yakni 30 puskesmas pernah dikirimkan obat expire date (ED) < 1 Tahun, 7 Puskesmas pernah dikirimkan obat yang sudah ED dan 26 puskesmas pernah dikirmkan obat yang tidak di pesan. Kendala yang paling sering dihadapi dalam pengadaan obat dan pendistribusian obat yang dilakukan oleh Instalasi Farmasi Dinas Kesehatan Kota Bandar Lampung yaitu obat kosong di PBF dan obat yang dikirimkan ke puskesmas tidak sesuai dengan yang diminta oleh puskesmas.

\section{SARAN}

Perlunya dilakukan penelitian yang sejenis di wilayah lain terutama di daerah dengan akses transportasi yang terbatas dan cakupan wilayah yang cukup luas. Dilakukan penelitian aspek managemen lainnya dalam standar pelayanan kefarmasian. Dilakukan analisa hubungan antara pengadaan dan distribusi obat dengan kualitas pelayanan di puskesmas

\section{DAFTAR PUSTAKA}

Boku, Y., Satibi, N. M. Y., \& Yasin, N. M. (2019). Evaluasi Perencanaan dan Distribusi Obat Program di Dinas Kesehatan Provinsi Sulawesi Tenggara. Jurnal Manajemen Dan Pelayanan Farmasi (Journal of Management and Pharmacy Practice), 9(2), 88-100.

Danu, S. S. (2013). Evaluasi penyimpanan dan distribusi obat di kabupaten lampung selatan (Doctoral dissertation, Universitas Gadjah Mada).

Departemen Kesehatan Republik Indonesia. (2007). Pedoman Pengelolaan obat publik dan perbekalan kesehatan. Ditjen Pelayanan Kefarmasian dan Alat Kesehatan, 7. Diakses dari: https://docplayer.info/30426285-Pedomanpengelolaan-obat-publik-dan-perbekalankesehatan-di-daerah-kepulauan.html

Departemen Kesehatan Republik Indonesia. (2008). Pedoman Teknis pengadaan obat publik dan perbekalan kesehatan untuk pelayanan kesehatan dasar. Jakarta (9). Diakses dari: https://adoc.tips/pedoman-teknis-pengadaan-obatpublik-dan-perbekalan-kesehata.html

Nopiyansyah"* Ikatan Apoteker Indonesia Daerah Lampung. *Email :ryan_farm06@yahoo.co.id

Anny Victor Purba ${ }^{2}$, Wahyudi Uun Hidayat ${ }^{3}$ Universitas Pancasila 
Evaluasi manajemen pengadaan dan distribusi obat di dinas kesehatan kota Bandar Lampung periode tahun 2016

Departemen Kesehatan Republik Indonesia. (2010). Pedoman Supervisi dan Evaluasi Obat Publik dan Perbekalan Kesehatan. Direktorat Jenderal Pelayanan Kefarmasian dan Alat Kesehatan Jakarta: Departemen Kesehatan RI. Diakses dari: http://perpustakaan.farmalkes.kemkes.go.id/upload ed_files/temporary/DigitalCollection/MTIzZjU4YWU 1MWVhNTFhZTBhMGRiZTI3N2UOYTEwN2NkZTM 2MGJjZQ==.pdf

Dwiprahasto, I. (2004). Ketersediaan obat di kabupaten dan mutu peresepan di pusat pelayanan kesehatan primer. Berkala llmu Kedokteran, 36(2004).

Dye, T. R. (2001). Top down policymaking. Chatham House Pub.

Herman, M. J. (2009). Eksistensi Unit Pengelola Obat Di Beberapa Kabupaten/Kota Suatu Analisis Paska Desentralisasi. Jurnal Manajemen Pelayanan Kesehatan, 12(04).

Kementerian Kesehatan Republik Indonesia, (2010). Materi Pelatihan Manajemen Kefarmasian di Instalasi Farmasi Kabupaten Kota. Kementerian Kesehatan RI. and Japan International Coorperation Agency (JICA), 28-32. Diakses dari: http://perpustakaan.farmalkes.kemkes.go.id/upload ed_files/temporary/DigitalCollection/MTIZZjU4YWU 1MWVhNTFhZTBhMGRiZTI3N2UOYTEwN2NkZTM $\underline{2 M G J j Z Q==. p d f}$

Kementerian Kesehatan Republik Indonesia, (2013). Peraturan Menteri Kesehatan Nomor 48 Tahun 2013. Petunjuk Pelaksanaan Pengadaan Obat Dengan Prosedur E-Purchasing Berdasarkan ECatalogue. Diakses dari: https://peraturan.bpk.go.id/Home/Details/129758/p ermenkes-no-48-tahun-2013
Keputusan Presiden Republik Indonesia, 2009). (2009). Undang-undang Republik Indonesia nomor 36 tahun 2009 tentang Kesehatan. Jakarta Republik Indones. Diakses dari: https://jdih.kemenkeu.go.id/fullText/2009/36TAHUN 2009UU.htm

Kristin, E. (2007). Proses pengadaan obat di Dinas Kesehatan Kabupaten Berau (Doctoral dissertation, [Yogyakarta]: Universitas Gadjah Mada)

Murwati, N. (2011). Analisis Manajemen Obat di Dinas Kesehatan Kabupaten Banyumas (Doctoral dissertation, Universitas Gadjah Mada).

Nurniati, L., Lestari, H., \& Lisnawaty, L. (2017). Studi Tentang Pengelolaan Obat di Puskesmas Buranga Kabupaten Wakatobi Tahun 2016. (Jurnal IImiah Mahasiswa Kesehatan Masyarakat), 1(3).

Quick, J. D., Hogerzeil, H. V., Rankin, J. R., Dukes, M. N. G., Laing, R., Garnett, A., \& O'Connor, R. W. (1997). Managing drug supply: the selection, procurement, distribution, and use of pharmaceuticals.

Syukriati, C. (2016). Evaluasi pengelolaan obat pada puskesmas di kota pariaman tahun 20132014 (Doctoral dissertation, Universitas Andalas).

Ukai, M. (2009). Evaluasi Manajemen Obat di Gudang Farmasi Dinas Kesehatan Kabupaten Raja Ampat Irian Jaya Barat (Doctoral dissertation, Universitas Gadjah Mada). 